\title{
PELATIHAN PENGELOLAAN DANA MASYARAKAT BERBASIS SYARI’AH
}

\author{
COMMUNITY-BASED FUNDS MANAGEMENT TRAINING SYARI'AH
}

\author{
Inna Kuswandari \\ Fakultas Sains dan Teknologi \\ Tika Widiastuti \\ Fakultas Ekonomi dan Bisnis
}

\begin{abstract}
ABSTRAK
Kegiatan pengabdian kepada masyarakat ini bertujuan meningkatkan kesadaran dan pemahaman masyarakat akan pentingnya implementasi prinsip syari'ah dalam pengelolaan dana dan kegiatan ekonomi sehari-hari. Manfaat yang diperoleh dari penerapan prinsip syari'ah selain harta lebih berkah juga tidak memberatkan bagi semua pihak yang terlibat transaksi ekonomi (adil). Metode yang digunakan dalam kegiatan ini meliputi penyuluhan (pelatihan) dan diskusi, proses pendampingan, serta evaluasi. Dengan pemberian materi tentang sistem syari'ah dan prinsip syari'ah yang dilaksanakan pada 3 Agustus 2017, warga masyarakat mendapat pencerahan dan mengaku lebih memahami sistem syari'ah. Luaran kegiatan ini adalah adanya kelompok masyarakat yang akan menerapkan prinsip syari'ah dalam mengelola dana. Selain dalam periode KKN-BBM ke-56, proses pendampingan dan evaluasi juga akan dilakukan bersamaan dengan pelaksanaan KKN-BBM periode berikutnya.
\end{abstract}

Kata kunci: Syariah, KKN-BBM

\section{ABSTRACT}

This community service activity aims to increase public awareness and understanding of the importance of implementing shari'ah principles in managing funds and daily economic activities. The benefits derived from the application of the shari'ah principle in addition to the more blessed assets are also not burdensome for all parties involved in economic transactions (fair). The methods used in this activity include counseling (training) and discussion, mentoring process, and evaluation. With the provision of material about the syari'ah system and the shari'ah principle that was implemented on August 3, 2017, the citizens got enlightenment and claimed to understand the shari'ah system more. The output of this activity is the existence of community groups that will implement the Shari'ah principle in managing funds. In addition to the 56th KKN-BBM period, the assistance and evaluation process will also be carried out in conjunction with the implementation of the next KKN-BBM period.

Keywords: Syariah, KKN-BBM

\section{PENDAHULUAN}

Secara geografis Kabupaten Jember terletak pada posisi

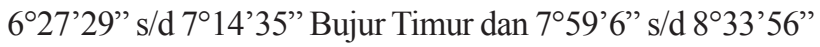
Lintang Selatan berbentuk dataran ngarai yang subur pada bagian tengah dan selatan, dikelilingi pegunungan yang memanjang sepanjang batas utara dan timur serta Samudra Indonesia sepanjang batas selatan dengan Pulau Nusa barong yang merupakan satu-satunya pulau yang ada di wilayah Kabupaten Jember. Letaknya yang strategis karena berada di persimpangan antara Surabaya dan Bali, sehingga perkembangannya cukup pesat dan menjadi barometer pertumbuhan ekonomi di kawasan timur Jawa Timur.

Sebagai daerah otonom, Kabupaten Jember memiliki batas-batas teritorial, luas wilayah, kemampuan ekonomi, potensi daerah, sosial politik dan sosial budaya, serta sumber daya manusia. Kondisi obyektif yang demikian dapat mengungkapkan berbagai karakteristik sumber daya alam, komoditas yang dihasilkan, mata pencaharian penduduk, keadaan serta ekonomi dan sosial budaya nya yang mencerminkan kekuatan sebagai suatu kompetensi daerah, 
sekaligus beragam permasalahan yang dihadapinya. Adapun batas-batas wilayah kabupaten Jember adalah (1) Utara: Kabupaten Bondowoso dan sedikit Kabupaten Probolinggo, (2) Timur : Kabupaten Banyuwangi, (3) Selatan : Samudera Indonesia, (4) Barat : Kabupaten Lumajang.

Kabupaten Jember memiliki luas wilayah 3.293,34 km2 atau 329.333,94 Ha. Dari segi topografi, sebagian Kabupaten Jember di wilayah bagian selatan merupakan dataran rendah yang relatif subur untuk pengembangan tanaman pangan, sedangkan di bagian utara merupakan daerah perbukitan dan bergunung-gunung yang relatif baik bagi pengembangan tanaman keras dan tanaman perkebunan.

Secara demografi, Kabupaten Jember pada dasarnya tidak mempunyai penduduk asli, hampir semuanya pendatang, mengingat daerah ini tergolong daerah yang mengalami perkembangan sangat pesat khususnya di bidang perdagangan, sehingga memberikan peluang bagi pendatang untuk berlomba-lomba mencari penghidupan di daerah ini. Mayoritas penduduk yang mendiami Kabupaten Jember adalah suku Jawa dan Madura, di samping masih dijumpai suku-suku lain serta warga keturunan asing sehingga melahirkan karakter khas Jember yang dinamis, kreatif, sopan, dan ramah tamah (http://jember.info/info/kondisiumum).

Secara geografis Kecamatan Rambipuji Kabupaten Jember terletak pada posisi 1130 s/d 1140 Bujur Timur dan 810 s.d 820 Lintang Selatan berbentuk dataran ngarai yang subur pada bagian tengah dan selatan, pegunungan yang memanjang sepanjang batas utara di Desa Gugut. Kecamatan Rambipuji ini berbatasan dengan Kecamatan Panti di sebelah Utara, berbatasan dengan Kecamatan Kaliwates di sebelah Timur, berbatasan dengan Kecamatan Ajung di sebelah Selatan, dan berbatasan dengan Kecamatan Bangsalsari di sebelah Barat. Secara administratif, Kecamatan Rambipuji terbagi menjadi 8 desa yang semuanya merupakan desa berkategori swasembada, yaitu Curah malang (Kodepos : 68152), Gugut (Kodepos : 68152), Kaliwining (Kodepos : 68152), Nogosari (Kodepos : 68152), Pecoro (Kodepos : 68152), Rambigundam (Kodepos : 68152), Rambipuji (Kodepos : 68152), dan Rowotamtu (Kodepos : 68152). (https://jemberkab.bps.go.id/website/pdf_publikasi/StatistikDaerah-Kecamatan-Rambipuji-2016.pdf)

Mayoritas penduduk Kecamatan Rambipuji adalah muslim. Di Kecamatan Rambipuji, kegiatan lingkup kelurahan, rukun warga (RW), rukun tetangga (RT), atau dasawisma masih berjalan secara kontinu, diantaranya pengajian, posyandu, dan arisan. Salah satu kegiatan rutin di kelompok dasawisma adalah arisan, yang di dalamnya mencakup bantuan pembiayaan usaha dalam bentuk simpan pinjam. Pemberian pinjaman ini dirasa sangat membantu bagi warga masyarakat yang membutuhkan. Pengembalian uang yang dipinjam selama ini menggunakan sistem bunga (dengan persentase tertentu dan jangka waktu tertentu pula), demikian pula bagi masyarakat yang menabung (menyimpan uang).

Sebagai pemeluk agama Islam, sistem seperti di atas jelas-jelas dilarang dalam ajaran Islam, sebab termasuk dalam kategori riba. Terlepas bahwa sistem pemberian bunga sangat memberatkan bagi peminjam, hal ini juga jauh dari keberkahan harta. Penerapan sistem bunga disebabkan beberapa hal, diantaranya ketidakpahaman bahwa pemberian bunga termasuk riba. Tidak adanya alternatif pengelolaan sumber pembiayaan berbasis syari'ah padahal masyarakat sangat membutuhkan pengetahuan yang memadai tentang konsep syari'ah dalam kegiatan ekonomi, maka pada kesempatan kali ini, kami dari Universitas Airlangga mengadakan kegiatan pengabdian kepada masyarakat bagi masyarakat Kecamatan Rambipuji bersamaan dengan pelaksanaan KKN-BBM angkatan ke-56 di Kecamatan Rambipuji.

Alternatif solusi untuk mengatasi permasalahan di atas adalah penerapan sistem pembiayaan usaha menurut Islam yang dikenal dengan sistem syari'ah mudharabah (bagi hasil). Tujuan kegiatan ini adalah meningkatkan kesadaran dan pemahaman masyarakat akan pentingnya prinsip syari'ah dalam kegiatan ekonomi sehari-hari, baik dalam skala kecil maupun yang lebih besar. Pada kesempatan ini, sasaran kegiatan adalah masyarakat desa Curah malang Kecamatan Rambipuji Kabupaten Jember yang tergabung dalam kelompok pengelola dana. Dampak dari kegiatan ini adalah meningkatnya pemahaman masyarakat akan pentingnya mengelola dana menggunakan sistem bagi hasil (syari'ah), karena selain lebih berkah dalam kehidupan juga tidak memberatkan pihak tertentu atau lebih adil bagi kedua belah pihak. Peningkatan pemahaman ini diukur melalui pre-tes sebelum pelatihan dan post-test setelah diberi pelatihan. Sebagai luaran kegiatan ini adalah bentuk pengelolaan dana berbasis syari'ah yang ditandai dengan adanya kelompok masyarakat yang telah melakukan persiapan penerapan sistem pengelolaan dana berbasis syari'ah.

\section{METODE PELAKSANAAN}

Secara umum, metode pelaksanaan dalam kegiatan ini meliputi penyuluhan dan diskusi, evaluasi, serta proses pendampingan. Materi diberikan kepada semua peserta dan disampaikan dalam bentuk power point agar mudah dipahami. Setelah memperoleh materi penyuluhan, diharapkan pengetahuan masyarakat tentang sistem syari'ah semakin bertambah dan mendorong mereka untuk dengan sukarela dan penuh kesadaran menerapkan sistem syari'ah. Pada pelatihan ini diberikan 2 materi dasar, yaitu:

1. Penyuluhan tentang pentingnya prinsip syari'ah dalam melakukan transaksi ekonomi kepada warga masyarakat yang tergabung dalam kelompok tertentu, misalnya perkumpulan ibu-ibu arisan, atau kelompok lain; 
2. pemberian materi/modul yang berisi tentang tinjauan prinsip syari'ah berdasarkan ilmu fiqih sesuai ajaran Islam dalam manajemen pengelolaan dana.

\section{HASIL DAN PEMBAHASAN}

Kegiatan pengabdian kepada masyarakat ini dilaksanakan secara bermitra atau kolaborasi antara tim pelaksana yang terdiri dari dosen Fakultas Sains dan Teknologi serta dosen dari Fakultas Ekonomi dan Bisnis Universitas Airlangga dengan warga masyarakat desa Curah malang Kecamatan Rambipuji Kabupaten Jember. Kegiatan ini juga melibatkan mahasiswa yang sedang melaksanakan kuliah kerja nyata angkatan ke-56 di Kabupaten Jember. Peran dari mitra (aparat desa Curah malang) antara lain memberikan gambaran nyata tentang permasalahan yang dihadapi dalam usaha peningkatan pemahaman pengelolaan dana yang berkah, dan memberikan masukan-masukan tentang rencana program yang tepat sasaran.

Kegiatan pengabdian kepada masyarakat ini diselenggarakan pada hari Kamis, 3 Agustus 2017 bertempat di balai desa Curah malang Kecamatan Rambipuji Kabupaten Jember. Kegiatan ini dihadiri oleh 50 orang warga masyarakat desa Curah malang Kecamatan Rambipuji Kabupaten Jember sebagaimana yang ditetapkan dalam rencana kegiatan, serta berlangsung mulai pukul 09.00-14.00 WIB.

Metode pelaksanaan yang digunakan dalam kegiatan pengabdian kepada masyarakat ini adalah penyuluhan dan diskusi, evaluasi, serta proses pendampingan. Tujuan dari penyuluhan adalah memberikan gambaran umum tentang pengelolaan dana masyarakat berbasis syari'ah dan selanjutnya dilakukan diskusi yang mendalam tentang sistem dan prinsip syari'ah. Penyuluhan dilakukan oleh pakar ekonomi syari'ah, yaitu Dr. Imron Mawardi, SP., M.Si., dosen Departemen Ekonomi Syariah FEB Universitas Airlangga. Pada saat penyuluhan terjadi interaksi secara langsung antara warga masyarakat dan tim pengabdian kepada masyarakat, sehingga ada forum diskusi dan tanya jawab terkait masalah yang dihadapi oleh warga masyarakat. Pada forum diskusi warga masyarakat aktif berbagi pengalaman, mengemukakan pendapat, serta mengajukan pertanyaan pada tim pengabdian kepada masyarakat mengenai seluk beluk sistem dan prinsip syari'ah dalam pengelolaan dana.

Setelah dilakukan penyuluhan dan diskusi, dilanjutkan dengan evaluasi tingkat pemahaman peserta menggunakan pos-tes, setelah sebelumnya diberikan pre-tes (sebelum penyuluhan dimulai). Dari isian pre-tes dan pos-tes yang terkumpul, peserta merasa lebih paham tentang prinsip syari'ah dan mendapat pencerahan adanya alternatif pengelolaan dana selain yang selama ini mereka pahami. Dengan demikian, diharapkan mereka akan lebih yakin untuk beralih ke sistem syari'ah setelah memperoleh penyuluhan.
Selanjutnya dilakukan pendampingan pada kelompok masyarakat yang akan menerapkan system syari'ah. Tujuan pendampingan adalah memberikan pemahaman dan memastikan bahwa terdapat kelompok warga masyarakat desa Curah malang yang akan menerapkan sistem syari'ah. Pendampingan dilakukan mulai proses persiapan hingga pelaksanaan. Monitoring secara berkala juga dilakukan untuk melihat sejauh mana warga telah menerapkan sistem syari'ah. Proses monitoring juga akan dilakukan pada periode KKN-BBM berikutnya di Kecamatan Rambipuji. Dengan bimbingan dan arahan dari tim pelaksana kegiatan pengabdian kepada masyarakat Universitas Airlangga, diharapkan masyarakat mitra dapat menjadi mitra binaan dari Universitas Airlangga agar program yang berkelanjutan dapat terlaksana dengan baik dan berkelanjutan.

\section{KESIMPULAN DAN SARAN}

Pelaksanaan pelatihan dalam rangka pengabdian kepada masyarakat mendapat sambutan yang sangat baik dari warga masyarakat desa Curah malang sebagai peserta pelatihan. Antusiasme peserta ditunjukkan dengan banyaknya peserta yang mengajukan pertanyaan saat forum diskusi. Hal ini menunjukkan bahwa tingkat partisipasi dan inisiatif peserta sangat baik, suatu hal yang patut dipertahankan. Adanya kelompok masyarakat yang berinisiatif menerapkan prinsip syari'ah juga menjadi luaran kegiatan ini.

Adanya kegiatan pengabdian kepada masyarakat ini dapat menjadi titik awal kerja sama tim pengemas UNAIR dengan pihak desa, dalam hal ini desa Curah malang. Dengan kegiatan ini, kerja sama yang lebih luas dapat dilanjutkan dengan menyelenggarakan kegiatan lanjutan. Kerja sama juga dapat dijalin dengan berbagai pihak dan fokus pada pemberdayaan masyarakat pedesaan, misal dengan pengurus BUMDES (Badan Usaha Milik Desa), tokoh masyarakat yang berpengaruh dan berperan dalam membentuk KUM (Kelompok Usaha Masyarakat), dan Dinas Koperasi kabupaten/kota. Selain itu, hal serupa dapat juga diterapkan pada kelompok masyarakat di desa lain selain Curah malang dalam lingkup kecamatan Rambipuji.

\section{DAFTAR PUSTAKA}

Statistik Daerah Kecamatan Rambipuji 2016, Katalog BPS 11010023509120, https://jemberkab.bps.go.id/website/ pdf_publikasi/Statistik-Daerah-Kecamatan-Rambipuji2016.pdf, diakses 10 Nopember 2017.

Topografi Kota Jember, http://nrc-tempurejo.blogspot. co.id/2010/01/topografi-kota jember.html, diakses 10 Nopember 2017. 